\title{
Preparation and Characterization of Some Metal Complexes with Heterocyclic Azo Ligand (4-SuBAI)
}

\author{
Abdullah M. A. Habiban* \\ Tamara A. Kareem***
}

*Department of Chemistry, College of Education for Women, University of Kufa

**Department of Chemistry, College of Science for Women, University of Baghdad

***Chemistry Research Center, Department of Materials Science, Ministry of Science

Received 7, November, 2013

Accepted 5, January, 2014

c) (1) (9)

EY No ND This work is licensed under a Creative Commons AttributionNonCommercial-NoDerivatives 4.0 International Licens

\section{Abstract:}

The preparation and characterization of the $\mathrm{Cu}$ (II), $\mathrm{Co}(\mathrm{II}), \mathrm{Ni}(\mathrm{II}), \mathrm{Zn}(\mathrm{II}), \mathrm{Cd}(\mathrm{II})$, and $\mathrm{Hg}$ (II) metal complexes of heterocyclic azo ligand 2-[(4-sulphamide phenyl) azo] -4,5-diphenyl imidazole (4-SuBAI) have been studied by elemental analysis, FT-IR and UV-Vis Spectroscopic, magnetic moment and molar conductance methods. The analytical data showed that all chelate complexes were prepared with (metalligand) ratio of (1:2).

The general formula of these complexes was $\left[\mathrm{ML}_{2} \mathrm{X}_{2}\right] . \mathrm{nH}_{2} \mathrm{O}$ [were $\mathrm{L}=2-\left[\left(4^{\prime}\right.\right.$ sulphamide phenyl) azo]-4,5-diphenyl imidazole and $\mathrm{X}=\mathrm{Cl}$, and the octahedral geometry were suggested for these complexes .

Key words: Characterization, Metal Complexes, Heterocyclic, Azo, Ligand.

\section{Introduction:}

Azo imidazole derivatives are very important class of chemical compounds receiving attention scientific research[1]. They are highly colored and have been used as dyes and pigments for along time.[2,3]. They are important in drugs[4], cosmeties[5], biological activities including antibacterial[6], coordination capacity[7] and participate in azo coupling reactions[8]. Azo imidazole molecule being the azo imine group ($\mathrm{N}=\mathrm{N}-\mathrm{C}=\mathrm{N}-$ ), which is $\pi$-acidic and stabilized low valant metal redox state[9]. The azo imidazole reagents does not have the same interst in research and investigation because of the rarity in the preparation of this kind of reagents although the imidazole was known before 150 years[10]. Anumber of these azo dyes have been used as chelating ligands[3,7,11]in addition of the uses as reagents in analytical chemistry[8,12].

The present study reports the preparation and spectral characterizeation of new azo imidazole ligand (4SuBAI) and some of its metal complexes.

\section{Material and Methods: 1-Apparatus and material}

All chemicals and solvents used and were of highest purity obtained from Fluka, Merck and BDH. The melting points of the compounds were determined on a Electro thermal, meltaing point 9300. Elemental analysis(C.H.N) were obtained using 1108 C.H.N elemental analyzer. IR 
speatra were recorded using $\mathrm{KBr}$ discs in the range $(4000-400) \mathrm{cm}^{-1}$ on FTIR Teast scan Shimaduz model 8400S .while the UV-Vis, spectra recorded in absolut ethanol on Shimaduz model 1650PC. The ${ }^{1}$ HNMR spectrometer (solvent DMSO-d $\mathrm{d}^{6}$ ) were recorded on Bruker DMX-500 Spectrophotometer$300 \mathrm{MHz}$ spectrometer with TMS, ALBayt University, Jordan.

The ${ }^{13}$ CNMR spectrometer (solvent DMSO-d ${ }^{6}$ ) were recorded on Bruker DMX-500 Spectrophotometer-300 $\mathrm{MHz}$ spectrometer, AL-Bayt University, Jordan. Mass spectrometer agilent technologies 5975 at 70C and MSD energy, Tarbiat Modarres University, Iran. Molar conductance measurements were determined in ethanol at room temperature by using conductivity bridge model $31 \mathrm{~A}$ and the $\mathrm{pH}$ measurements were carried out using aphilips pw $9421 \mathrm{pH}$ meter $(\mathrm{pH} \pm 0.001)$. The metal contents of the complexes were measured by using atomic absorption techique by shimadzu AA-160. Magnetic susceptibilities were measured by using Faraday method blanc magnetic technique.

\section{2-Preparation of the ligand (4-}

\section{SuBAI)}

The hetero cyclic azo ligand was prepared according to the general method [13] by dissolving (4.03gm, $0.01 \mathrm{~mol}$ ) of sulfanilamide in $2 \mathrm{ml}$ of concentrated hydrochloric acid, $10 \mathrm{ml}$ ethanol and $10 \mathrm{ml}$ distilled water. To this mixture a solution of $10 \%$ of sodium nitrate in dissolved distilled water was added dropwise at $(0-5){ }^{\circ} \mathrm{C}$ and left to stand $15 \mathrm{~min}$. This diazonium solution was added dropwise into a $1000 \mathrm{ml}$ beaker containing $(2.2 \mathrm{gm}, 0.01 \mathrm{~mol})$ of 4,5 diphenyl imidazole dissolved in $(150 \mathrm{ml})$ ethanol and $(50 \mathrm{ml})$ sodium hydroxide $(10 \%)$ solution at $(0-5){ }^{\circ} \mathrm{C}$, the mixture was stirred in ice-bath and allowed to stand over night and acidified with dilute hydrochloric acid to $\mathrm{pH}=6$ ). The precipitate was filtered off, washed with distilled water and recrystallized ice from hot ethanol and dried in oven at $60{ }^{\circ} \mathrm{C}$ for 24 hour. The yield was $75 \%$ of dark orange crystals the procedure was seen in scheme1.

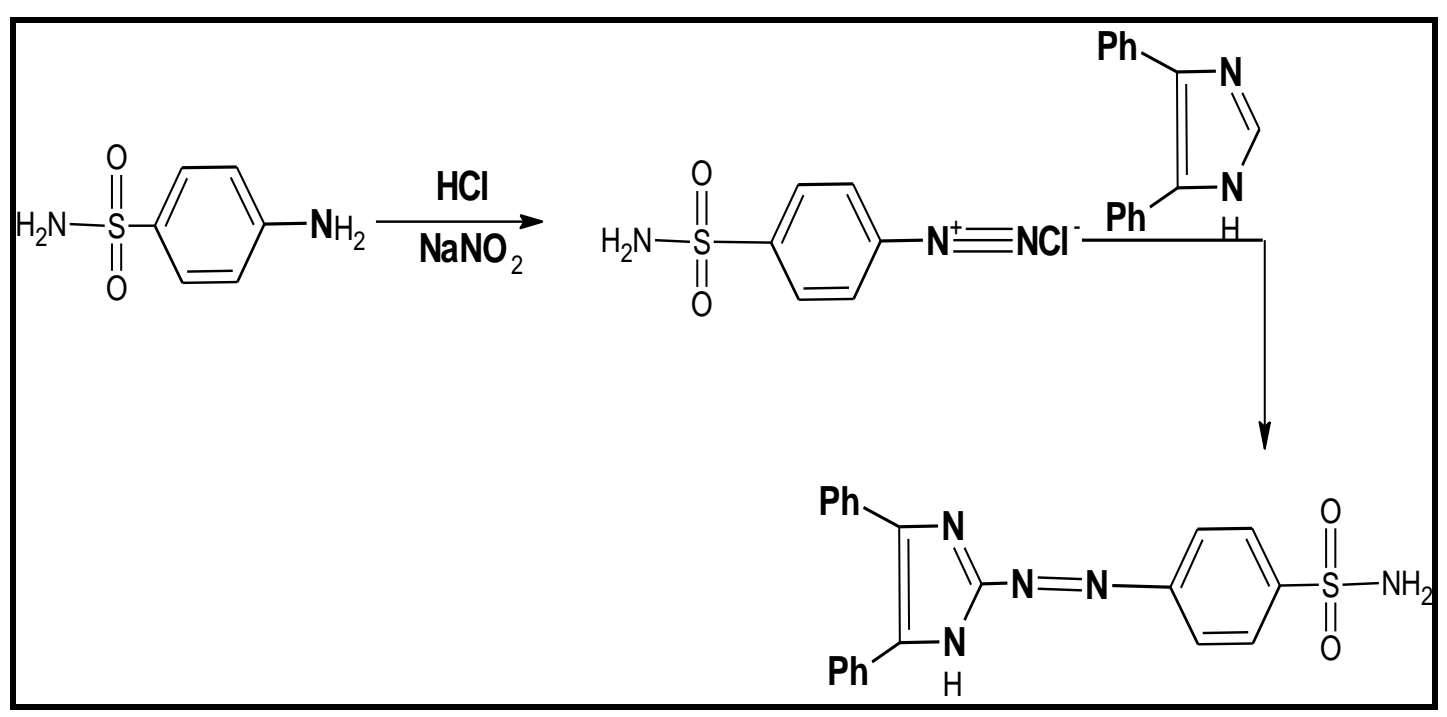

Scheme(1) :-Preparation of the ligand (4-SuBAI)

\section{3-Preparation of complexes}

The metal complexes were prepared by dissolved $(0.698 \mathrm{gm}, 0.002$ $\mathrm{mol})$ from ligand in ethanol $(5 \mathrm{ml})$ and added dropwise with stirring to $(0.001 \mathrm{~mol})$ metal salts as a $1: 2$ (metal:ligand) molar ratio of $\mathrm{Cu}(\mathrm{II})$, $\mathrm{Co}(\mathrm{II}), \mathrm{Ni}(\mathrm{II}), \mathrm{Zn}(\mathrm{II}), \mathrm{Cd}(\mathrm{II})$ and $\mathrm{Hg}(\mathrm{II})$ 
chlorides salts dissolving in buffer solution (ammonium acetate) at optimal $\mathrm{pH}$ for each metal ions. The solid product thus formed was filtered off from the ice-cooled reaction mixture, washed with $10 \mathrm{ml}$ hot ethanol to remove the remaining unreacted substances and left to dried at room temperature.

\section{Result and Discussion:}

Table(1): Analytical data and physical properties of the ligand (4-SuBAI) and it's complexes.

\begin{tabular}{|c|c|c|c|c|c|c|c|c|c|c|c|}
\hline \multirow[t]{2}{*}{ No. } & \multirow{2}{*}{ Compound } & \multirow{2}{*}{$\begin{array}{c}\text { Optimal } \\
\text { pH }\end{array}$} & \multirow[t]{2}{*}{ Color } & \multirow{2}{*}{$\underset{{ }^{\circ} \mathbf{C}}{\mathbf{m} . \mathbf{P}}$} & \multirow{2}{*}{$\begin{array}{l}\text { Yield } \\
\%\end{array}$} & \multicolumn{2}{|c|}{ Metal analysis \% } & \multicolumn{4}{|c|}{$\begin{array}{l}\text { \%Element analysis Calc. } \\
\text { (Found) \% }\end{array}$} \\
\hline & & & & & & Calculat. & Found & $\mathbf{C}$ & $\mathbf{H}$ & $\mathbf{N}$ & $\mathbf{S}$ \\
\hline 1 & $\mathrm{~L}=(4-\mathrm{SuBAI})$ & 6 & $\begin{array}{c}\text { Dark } \\
\text { orange }\end{array}$ & $\begin{array}{l}258- \\
260\end{array}$ & 75 & - & - & $\begin{array}{c}62.53 \\
(63.65)\end{array}$ & $\begin{array}{c}4.21 \\
(4.58)\end{array}$ & $\begin{array}{l}17.36 \\
(16.57\end{array}$ & $\begin{array}{c}7.94 \\
(7.36)\end{array}$ \\
\hline 2 & {$\left[\mathrm{CuL}_{2} \mathrm{Cl}_{2}\right] . \mathrm{H}_{2} \mathrm{O}$} & 8 & Magenta & $\begin{array}{l}150- \\
152\end{array}$ & 79 & 6.57 & 6.48 & - & - & - & - \\
\hline 3 & $\begin{array}{c}{\left[{\left.\mathrm{Co} \mathrm{L}_{2} \mathrm{Cl}_{2}\right]}_{. \mathrm{H}_{2} \mathrm{O}}\right.} \\
\end{array}$ & 7.5 & $\begin{array}{c}\text { Dark } \\
\text { brown }\end{array}$ & $\begin{array}{l}121- \\
123 \\
\end{array}$ & 71 & 6.17 & 5.99 & - & - & - & - \\
\hline 4 & {$\left[\mathrm{Ni} \mathrm{L}_{2} \mathrm{Cl}_{2}\right] . \mathrm{H}_{2} \mathrm{O}$} & 6.5 & $\begin{array}{l}\text { Brown } \\
\text { orange }\end{array}$ & $\begin{array}{l}199- \\
201\end{array}$ & 70.8 & 6.15 & 6.22 & - & - & - & - \\
\hline 5 & $\begin{array}{c}{\left[\mathrm{Zn} \mathrm{L}_{2} \mathrm{Cl}_{2}\right]} \\
. \mathrm{H}_{2} \mathrm{O}\end{array}$ & 7 & Orange & $\begin{array}{l}187- \\
189\end{array}$ & 63.5 & 6.75 & 6.43 & - & - & - & - \\
\hline 6 & $\begin{array}{c}{\left[\mathrm{Cd} \mathrm{L}_{2} \mathrm{Cl}_{2}\right]} \\
. \mathrm{H}_{2} \mathrm{O}\end{array}$ & 7 & $\begin{array}{l}\text { Bright } \\
\text { reed }\end{array}$ & $\begin{array}{l}203- \\
205\end{array}$ & 77 & 11.07 & 10.92 & - & - & - & - \\
\hline 7 & $\begin{array}{c}\left.\mathrm{Hg} \mathrm{L}_{2} \mathrm{Cl}_{2}\right] \\
. \mathrm{xH}_{2} \mathrm{O}\end{array}$ & 6.5 & $\begin{array}{l}\text { Bright } \\
\text { reed }\end{array}$ & $\begin{array}{l}212- \\
214\end{array}$ & 79 & - & - & - & - & - & - \\
\hline
\end{tabular}

3.1- Mass, ${ }^{1}$ HNMR and ${ }^{13}$ CNMR spectrum of new ligand (4-SuBAI) :

The mass spectrum of (4-SuBAI) a number group of peaks, figure-1- and scheme 2 , while ${ }^{1} \mathrm{HNMR}$ and ${ }^{13} \mathrm{CNMR}$ spectrum, figures 2 and 3, showed the following data $[7.35-7.50(\mathrm{dd}, 2 \mathrm{H}$
The reaction of heterocyclic azo ligand(4-SuBAI) with the metal ions mentioned above different color crystals depending on the nature of metal ion. The complexes were insoluble in water but soluble in most organic solvents. The analytical and physical data of the ligand and it's complexes are given in table 1 .

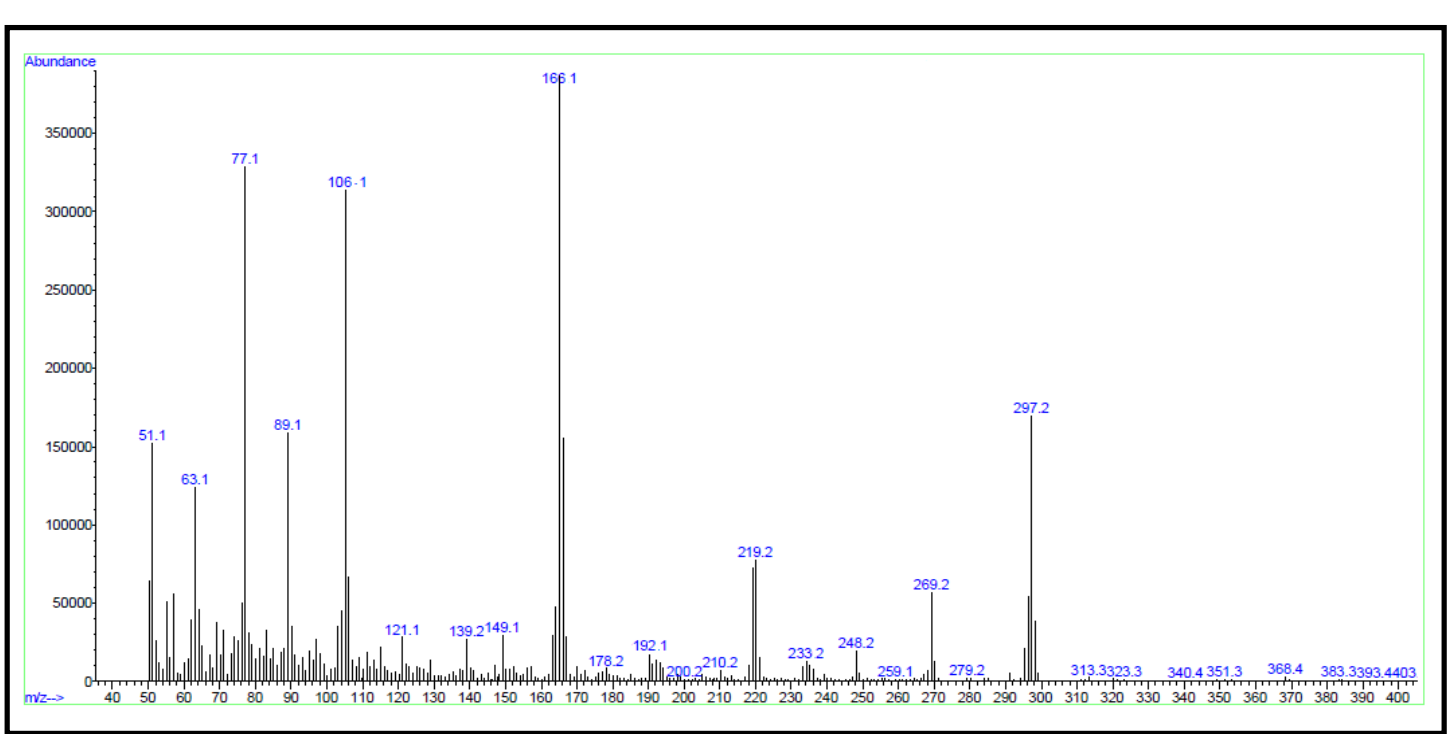

Fig. (1): Mass spectrum of new ligand (4-SuBAI). 


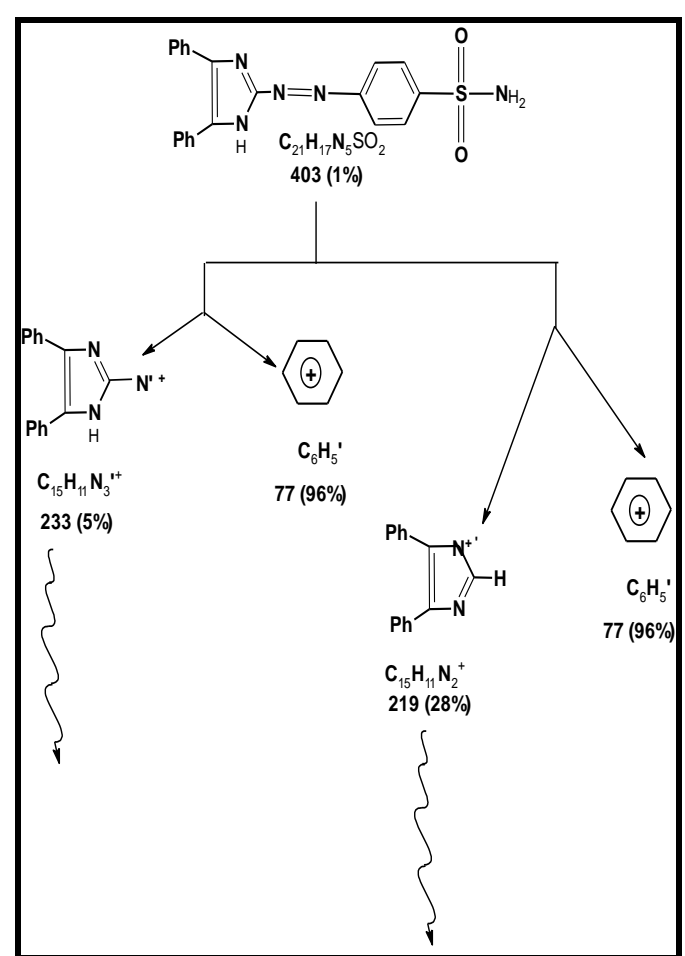

Scheme(2): Fragmentation pattern of ligand(4-SuBAI).

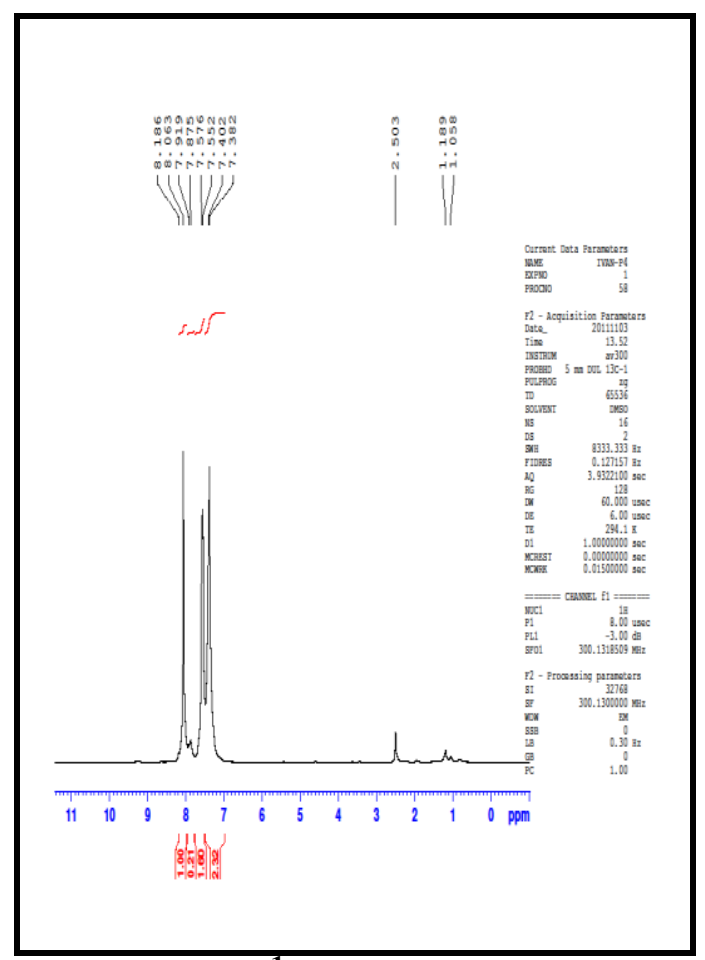

Fig.(2): The ${ }^{1}$ HNMR spectrum of ligand (4-SuBAI).

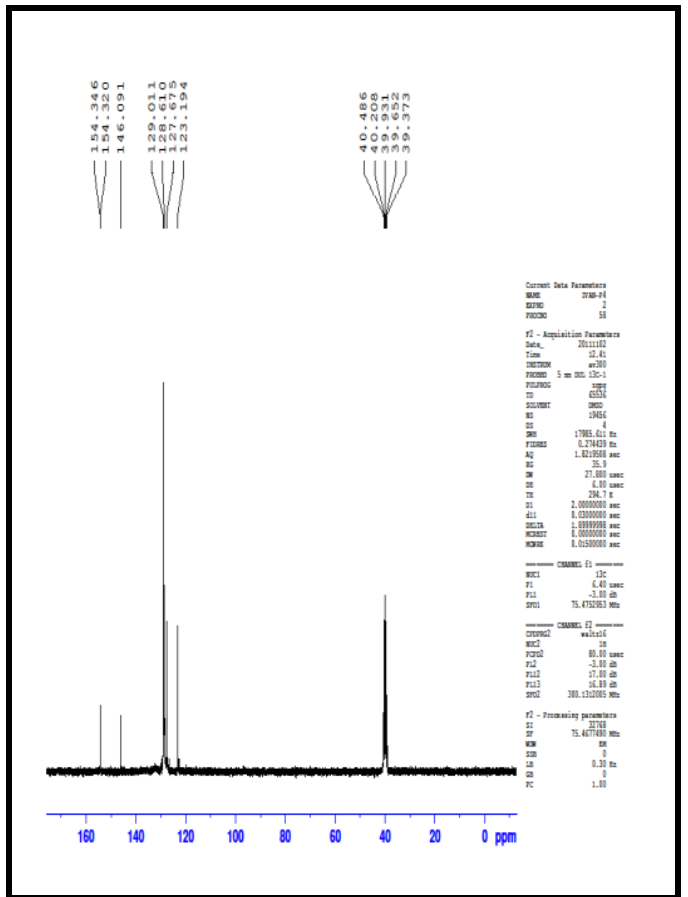

Fig.(3): The ${ }^{13}$ CNMR of ligand (4SuBAI).

\section{2- Effect of $\mathrm{pH}$ and concentration:}

The molar concentration of the solution of the prepared compounds were within the range $10^{-3}-10^{-6}$ molar, while the $\mathrm{pH}$ range was between 4 to 11. These concentrations are not all suitable in regard to the spectroscopic measurements.

The molar concentration that obey Lambert-Beer's law and showed a clear intense color at $2.5 \times 10^{-5} \mathrm{M}$, while the optimum $\mathrm{pH}$ values in buffer solution are shown in figures 4 , have been studied in buffer solution. 

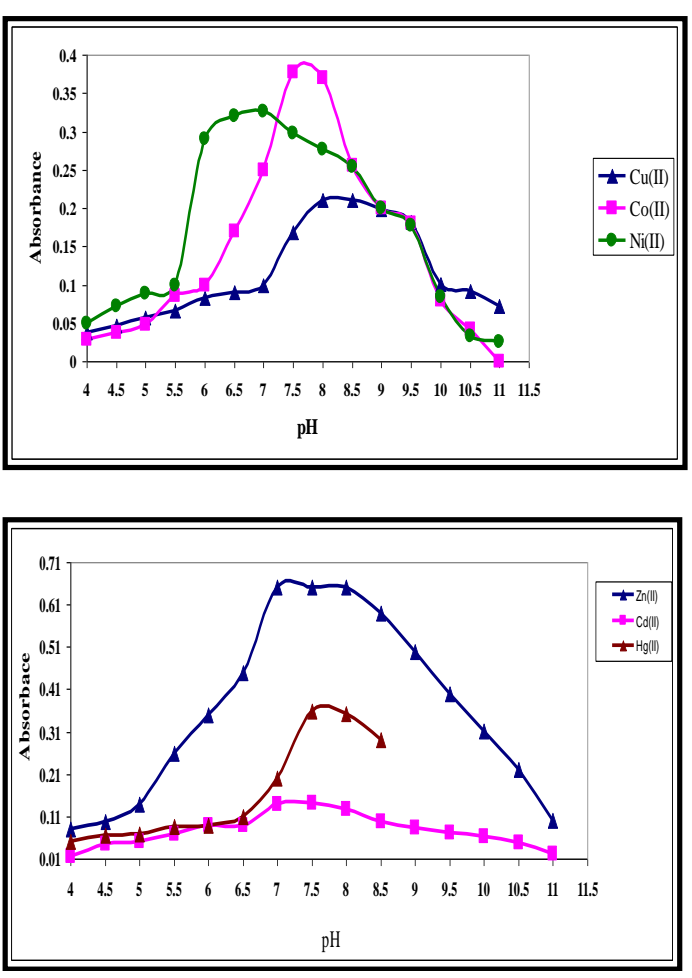

Fig.(4): Effect of pH on absorbance at $\left(\lambda_{\max }\right)$ for $(4-\mathrm{SuBAI})$ complexes at optimum concentration.

\section{3--Metal:ligand ratios}

Composition of chelate complexes were investigated by mole ratio method at fixed concentration of metal ion $\left(2.5 \times 10^{-5} \mathrm{M}\right)$ and increasing concentration of ligand at optimum $\mathrm{pH}$ and $\lambda_{\text {mex }}$. This method indicated that the more probable structure of complex was 1:2 for all complexes as shown in figures $5-10$.

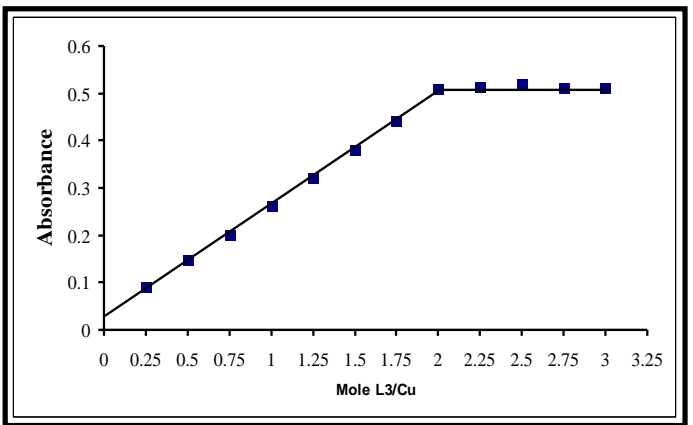

Fig.(5): Mole ratio plot for ligand $\mathrm{Cu}$ complex solution.

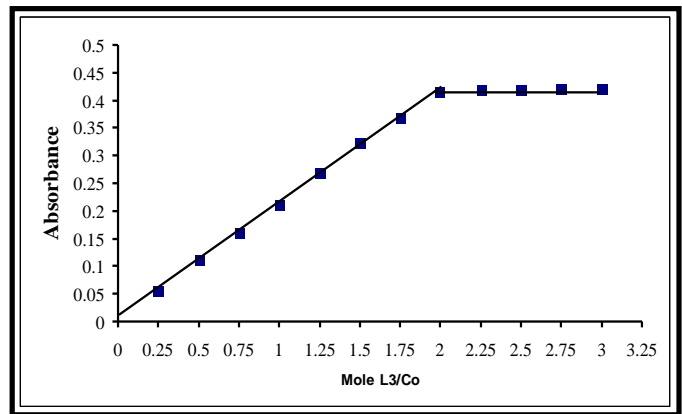

Fig.(6): Mole ratio plot for ligand Co complex solution.

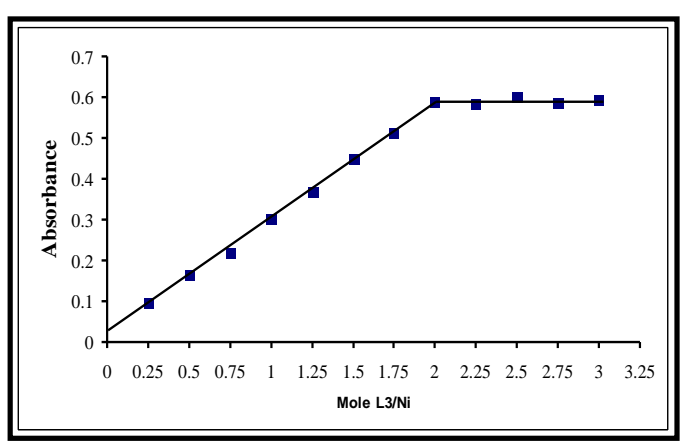

Fig.(7): Mole ratio plot for ligand Ni complex solution.

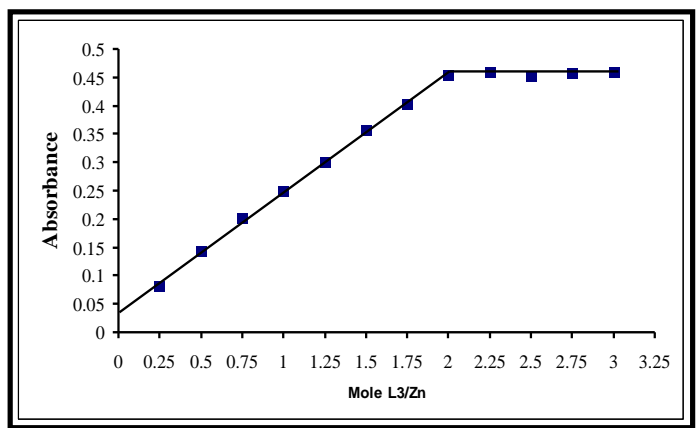

Fig.(8): Mole ratio plot for ligand $\mathrm{Zn}$ complex solution.

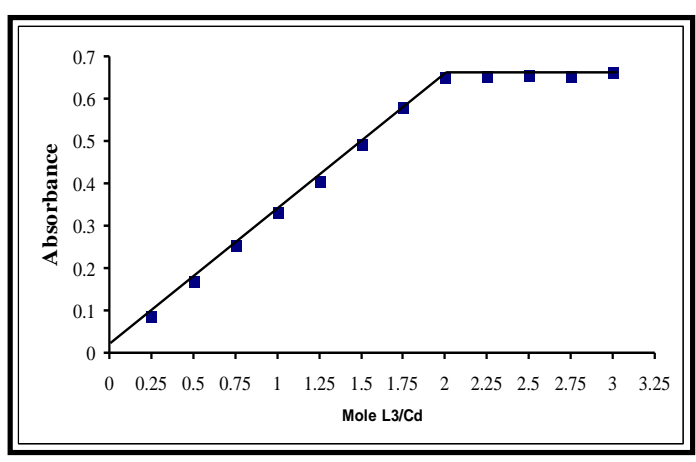

Fig. (9): Mole ratio plot for ligand Cd complex solution. 


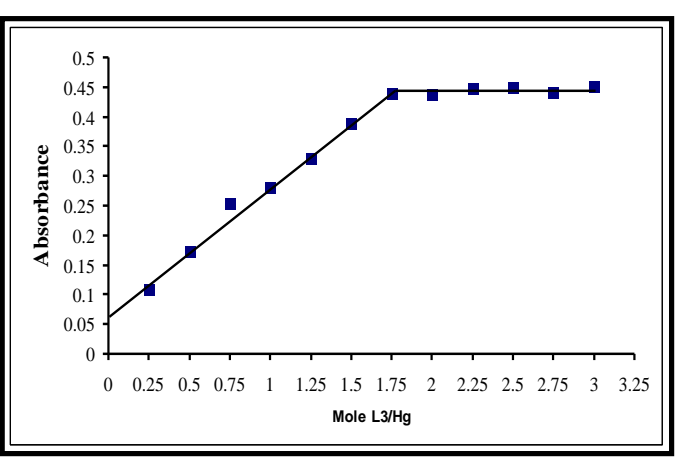

Fig.(10): Mole ratio plot for ligand Hg complex solution.

\section{4-Determination of the metal complexes stability constants}

Stability constant $(\beta)$ values are obtained spectrophotometrically by measuring the absorbance of a mixture of ligand and metal solution at fixed wavelength $\left(\lambda_{\max }\right)$ and optimum $\mathrm{pH}$ values. The degree of formation of the complexes are obtained from the relationship[14], $\beta=\left(1-\alpha / 4 \alpha^{3} c^{2}\right)$ for $1: 2$ metal complexes and $\beta=\left(1-\alpha / \alpha^{2} c\right)$ for 1:1 metal chelate and $\alpha=\mathrm{Am}-\mathrm{As} / \mathrm{Am}$ where As and Am are the absorbance of the partially and fully formed complex respectively at optimium concentration. The calculated $\beta$ and $\log$ $\beta$ values for the prepared complexes are given in table2.

\section{5-Molar conductivity}

The data obtained from the measurement of molar conductance of the complexes are shown in table (2) were carried out in ethanol $\left(10^{-3} \mathrm{M}\right)$ at room temperature. The values indicate that the chelate complexes of $\mathrm{Co}$ (II) $, \mathrm{Ni}(\mathrm{II}), \mathrm{Cu}(\mathrm{II})$ and $\mathrm{Pd}(\mathrm{II})$ ions are nonelectrolytes nature.[15]

Table (2) : metal :ligand stability constant values molar conductivity optimal concentration and wavelength with $(\epsilon)$ of chelate complexes.

\begin{tabular}{|c|c|c|c|c|c|c|}
\hline $\begin{array}{c}\text { Metal } \\
\text { Ions }\end{array}$ & $\begin{array}{c}\text { M: } \mathbf{L} \\
\text { ratio }\end{array}$ & $\left(\lambda_{\text {max }}\right) \mathbf{n m}$ & Optimum $\mathbf{~ H ~}$ & $\begin{array}{c}(\mathbf{G}) \mathbf{x 1 0} \\
\mathbf{L} \cdot \mathbf{m o l}^{\mathbf{1}} \mathbf{. c m}^{\mathbf{1}}\end{array}$ & $\begin{array}{c}\boldsymbol{\beta} \\
\mathbf{L}^{\mathbf{2}} \cdot \mathbf{m o l}^{-\mathbf{2}}\end{array}$ & $\begin{array}{c}\text { Molar } \\
\mathbf{c o n d u c t i v i t y}^{\mathbf{2}}\end{array}$ \\
\hline $\mathrm{Cu}(\mathrm{II})$ & $1: 2$ & 513 & 8 & 3.0920 & $1.988 \times 10^{15}$ & 1.06 \\
\hline $\mathrm{Co}(\mathrm{II})$ & $1: 2$ & 476 & 7.5 & 3.4600 & $1.089 \times 10^{15}$ & 13.40 \\
\hline $\mathrm{Ni}(\mathrm{II})$ & $1: 2$ & 469 & 6.5 & 3.5160 & $1.2947 \times 10^{15}$ & 0.95 \\
\hline $\mathrm{Zn}(\mathrm{II})$ & $1: 2$ & 460 & 7 & 2.5680 & $1.1177 \times 10^{14}$ & 13 \\
\hline $\mathrm{Cd}(\mathrm{II})$ & $1: 2$ & 460 & 7 & 4.3000 & $8.616 \times 10^{13}$ & 3.23 \\
\hline $\mathrm{Hg}(\mathrm{II})$ & $1: 2$ & 444 & 6.5 & 3.4080 & $2.689 \times 10^{13}$ & 3.69 \\
\hline
\end{tabular}

\section{6-FT-IR spectra}

Infrared spectra data ( $\mathrm{KBr}$ disk) of ligand (4-SuBAI) and its complexes are summarized in table(3). The comparison between spectrum of the ligand with those of the coordination complexes have, table(3), figures(1117) revealed certain characteristic differences. The most significant information on the geometry of these complexes comes from the $\mathrm{C}=\mathrm{N}$ group of imidazole, and the azo bridge absorption regions.

1. The FT-IR spectrum of the ligand 4SuBAI show bands in the range (3247) $\mathrm{cm}^{-1}$ corresponding to
$v(\mathrm{OH})$. This band showed, sometimes, a remarkable change in the intensity and broadening upon complexation.

2. The spectra also show weak bands located in the regions (3056 and 2970) $\mathrm{cm}^{-1}$ which were assigned to the aromatic and aliphatic $(\mathrm{C}-\mathrm{H})$ stretching vibrations, respectively.

3. Band were observed within the range $(1600) \mathrm{cm}^{-1}$, this band was attributed to $v(\mathrm{C}=\mathrm{N})$ spectra. On complexation a small shift with change in shape were observed for this band. That changed may be a result of coordination of metal ions 
through the nitrogen of imidazole $(\mathrm{C}=\mathrm{N})$ group.

4. Bands characteristic of the azo bridge vibrations have been attributed to the positions [(1396), (1423) and (1458) $\mathrm{cm}^{-1}, 1180 \mathrm{~cm}^{-1}$ and $[(800)$ and $(840)] \mathrm{cm}^{-1}$. The first three group band positions were assigned to the $v(\mathrm{~N}=\mathrm{N})$ while the second group represents the vibrations of $v(\mathrm{C}-\mathrm{N}=\mathrm{N}-\mathrm{C})+v($ $\mathrm{N}=\mathrm{N}$ ), and the third group band positions represents $v(\mathrm{C}-\mathrm{N}=\mathrm{N}-\mathrm{C})$ $+v(\mathrm{C}=\mathrm{N})$. On complexation, a small shift were observed for the $v($ $\mathrm{N}=\mathrm{N}$ ) stretching vibrations, while shifting or splitting was recommended for the bands represents the $v(\mathrm{C}-\mathrm{N}=\mathrm{N}-\mathrm{C})+\mathrm{v}($ $\mathrm{N}=\mathrm{N}$ ).
5. Significant changes were also observed for the thrid bands $v($ $\mathrm{C}-\mathrm{N}=\mathrm{N}-\mathrm{C})+\mathrm{v}(\mathrm{C}=\mathrm{N})$, indicating the engagement of those groups in the coordination with the metal ions.

6. A group of bands located at (1095) $\mathrm{cm}^{-1}$ and [(723),(723)and (763)] $\mathrm{cm}^{-}$ ${ }^{1}$ assigned to the Benz.R.Deff. and Imi.R.Deff. frequency respectively. Those bands effected on complexation through splitting, shifted or changing in their shapes.

7. The FT-IR showed bands at [(12171218) and (1338) $\mathrm{cm}^{-1}$ attributed to sulfonamide group. These bands non effected on complexation.

8. New band assigned to $v(\mathrm{M}-\mathrm{N})$ in the range (483-486) $\mathrm{cm}^{-1}$ appeared on complexation, which proved the coordination of metal ions with ligands through nitrogen atom.

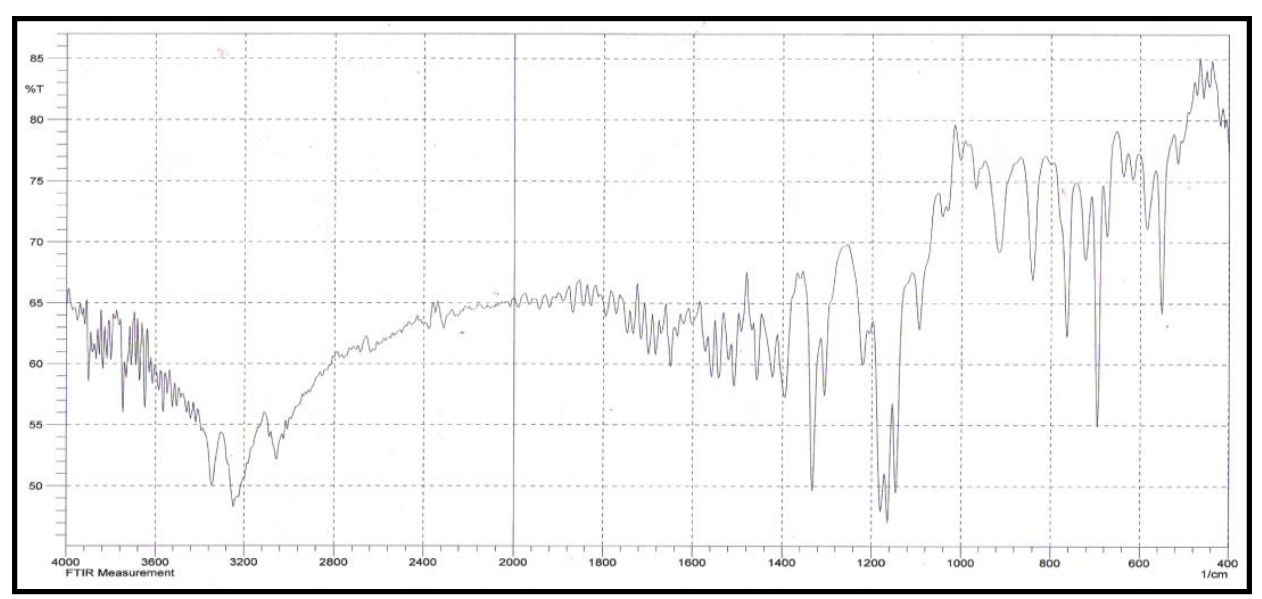

Fig.(11): IR- spectrum of ligand (4-SuBAI) .

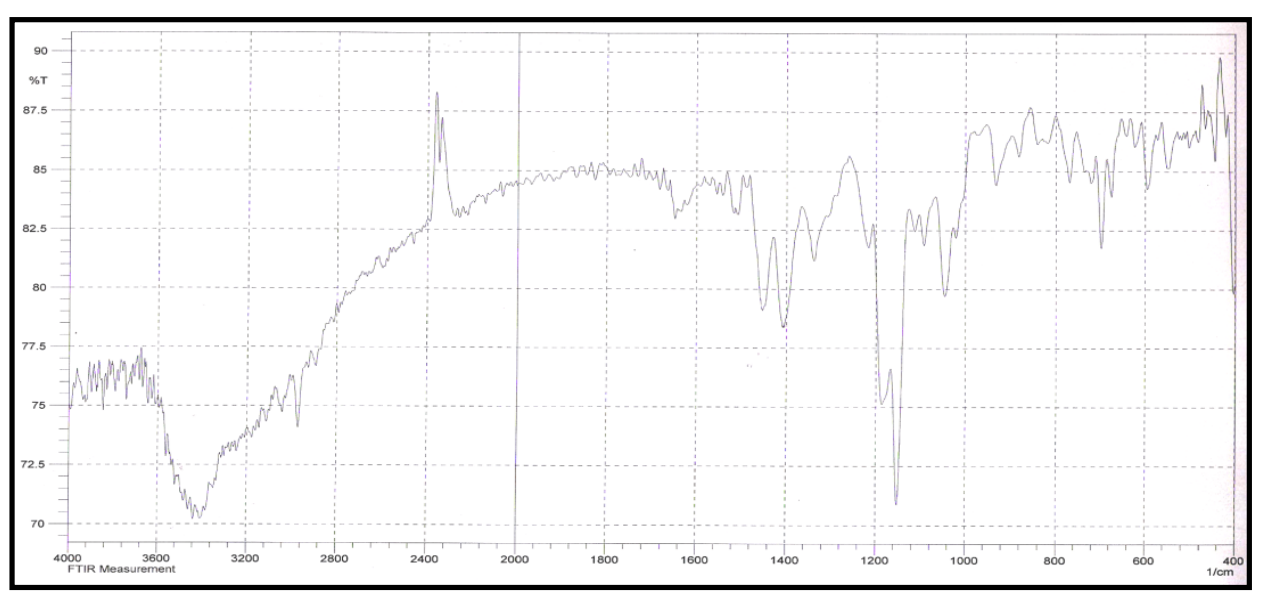

Fig.(12): IR- spectrum of [Cu (4-SuBAI) $\left.{ }_{2} \mathrm{Cl}_{2}\right]$. 


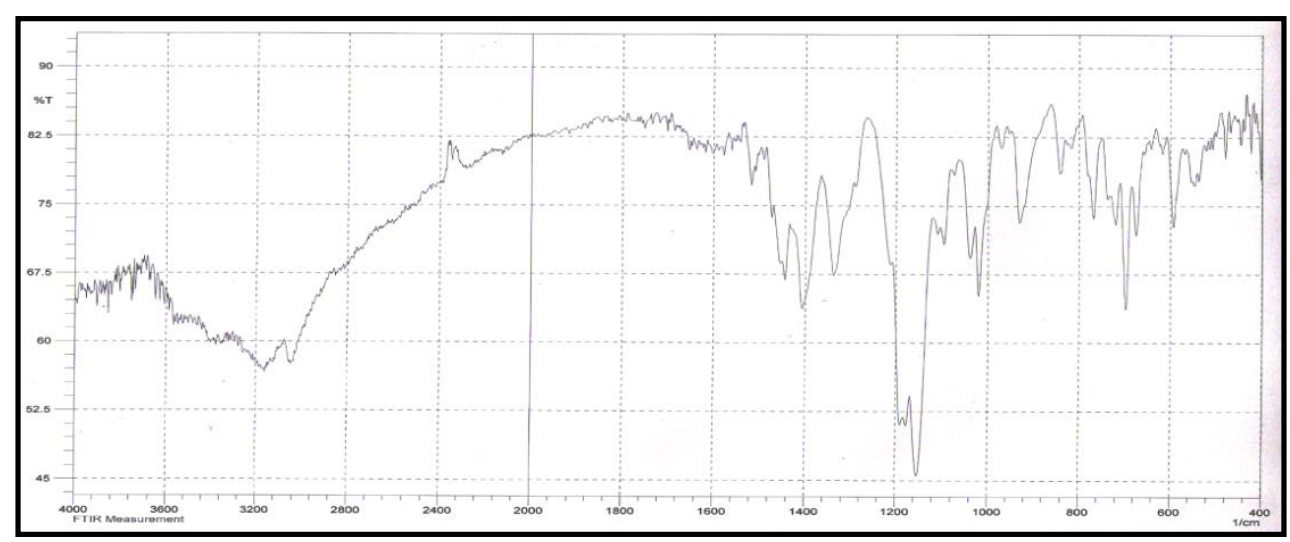

Fig.(13): IR- spectrum of [Co (4-SuBAI $)_{2} \mathrm{Cl}_{2}$ ]

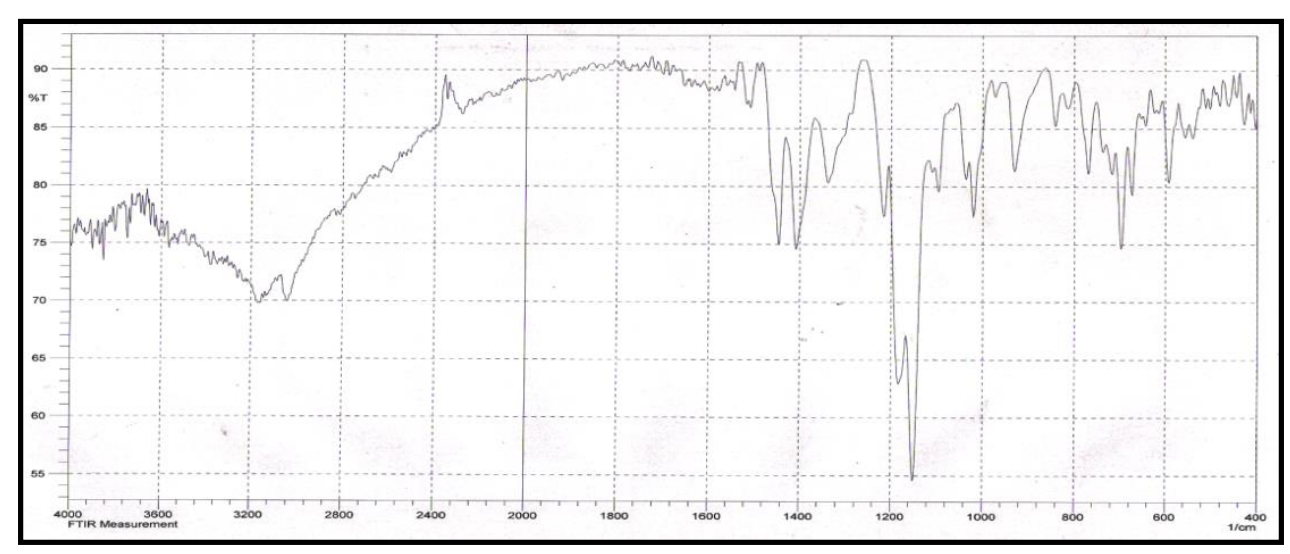

Fig.(14): IR- spectrum of [Ni (4-SuBAI $\left.)_{2} \mathrm{Cl}_{2}\right]$.

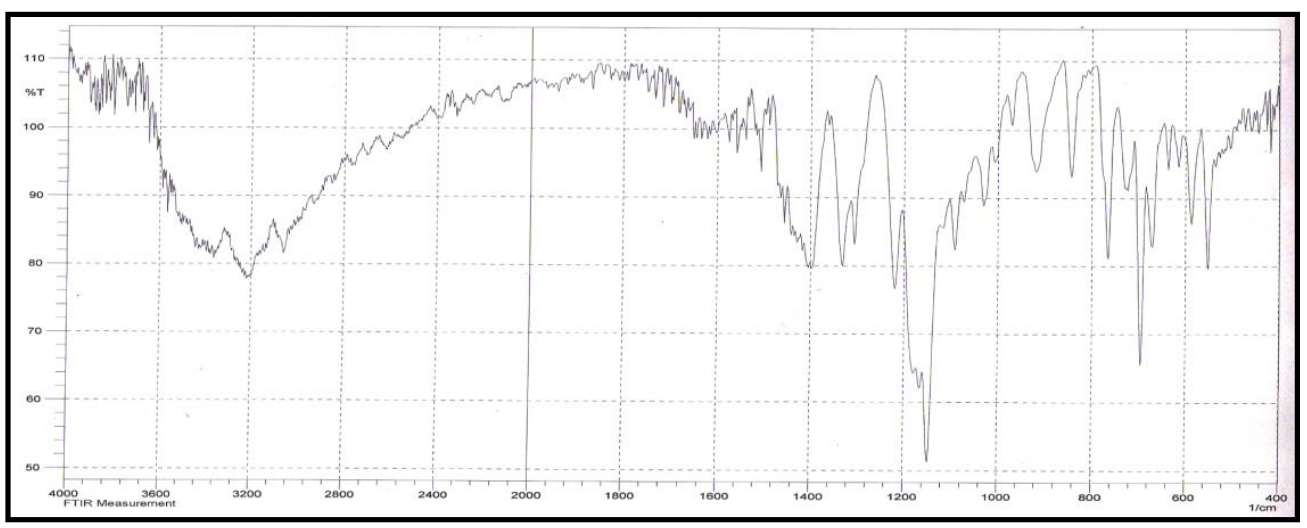

Fig.(15): IR- spectrum of [ $\left.\mathrm{Zn}(4-\mathrm{SuBAI})_{2} \mathrm{Cl}_{2}\right]$.

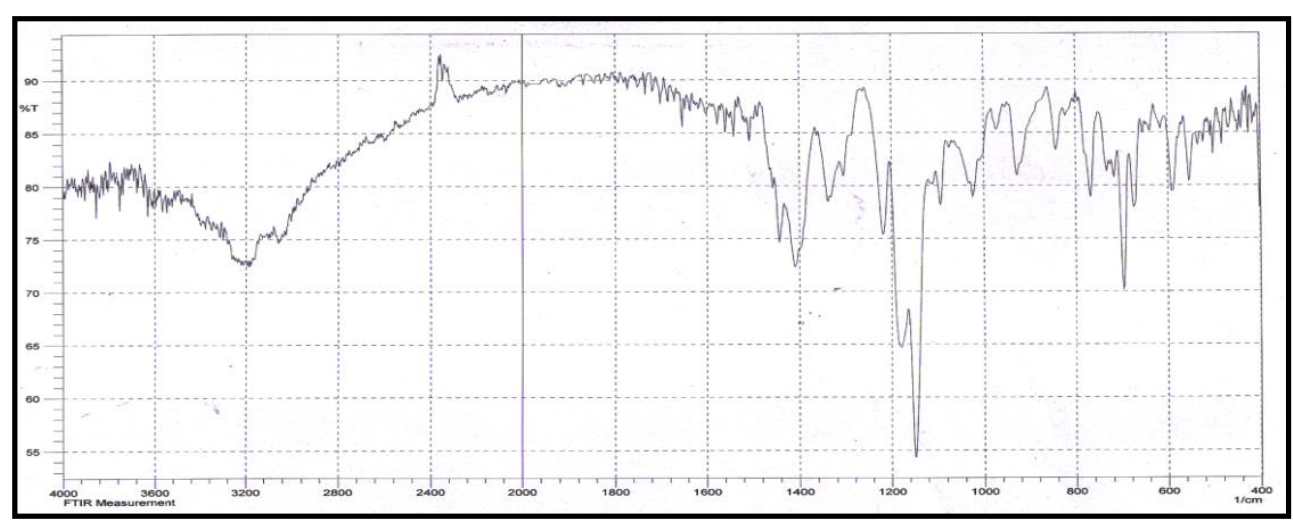

Fig.(16): IR- spectrum of [Cd (4-SuBAI) $\left.{ }_{2} \mathrm{Cl}_{2}\right]$. 


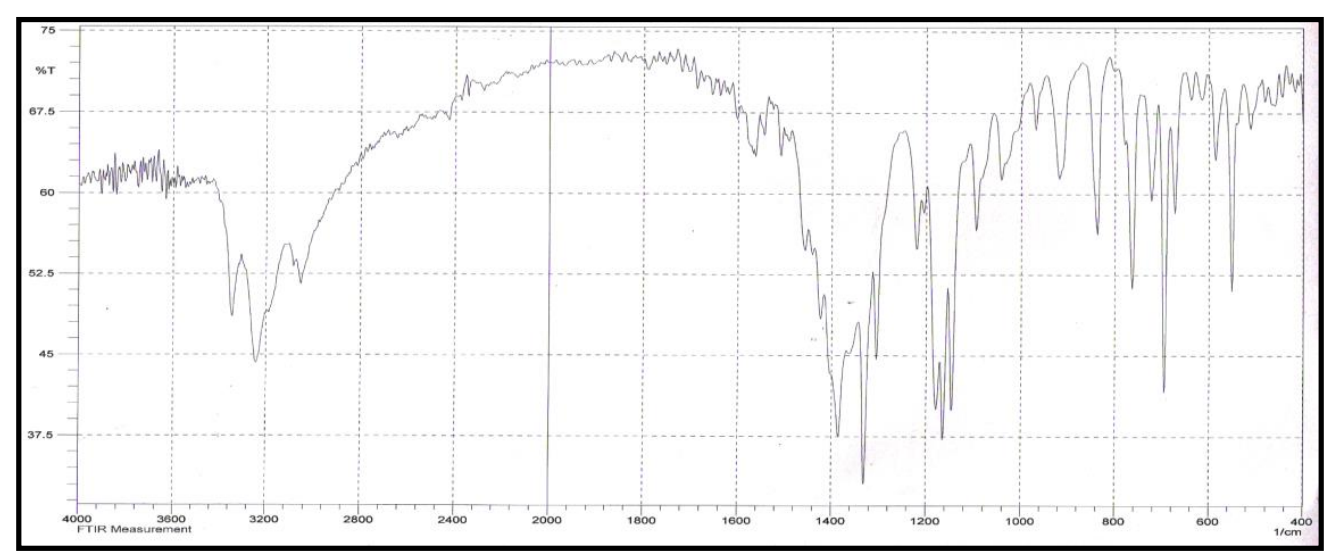

Fig.(17): IR- spectrum of [ $\left.\mathrm{Hg}(4-\mathrm{SuBAI})_{2} \mathrm{Cl}_{2}\right]$.

\begin{tabular}{|c|c|c|c|c|c|c|c|}
\hline 差家 & 䛜兽 & 部兽 & 量兽 & 粱 & 点兽 & 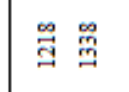 & 氬兽 \\
\hline 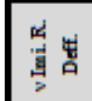 & 27 & 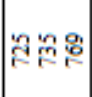 & 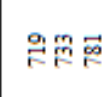 & 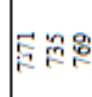 & 결: & 열움응 & 굴울 \\
\hline 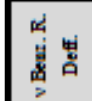 & s. & 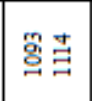 & 呂骂 & 兽罗 & 影总 & 贑兽 & 客兽 \\
\hline$\overline{\underline{t}}$ & 1 & 喿 & 嗬 & 尊 & 哥 & 觉 & 岛 \\
\hline 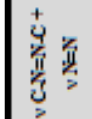 & $\stackrel{\circ}{\Xi}$ & $\stackrel{\circ}{g}$ & $\stackrel{8}{g}$ & $\stackrel{g}{\exists}$ & $\stackrel{\infty}{\Xi}$ & $\stackrel{\infty}{\Xi}$ & 葛兑 \\
\hline 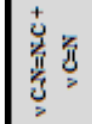 & 옴욤 & $\overrightarrow{\sigma^{\prime}}$ & 哃品 & 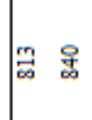 & 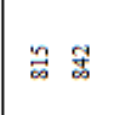 & 唡高 & 总留 \\
\hline 畜 & $\stackrel{8}{\circ}$ & $\mid \begin{array}{l}\mathscr{D} \\
\stackrel{g}{a}\end{array}$ & 足 & g: & 吕 & 夠 & $\stackrel{\mathscr{0}}{:}$ \\
\hline 普 & 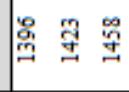 & 埕哥 & 燝表等 & 車星 & 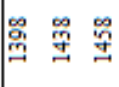 & 量哇告 & 各垔墨 \\
\hline 急票 & 总 & 蔒 & 亶 & 第 & : & 㸃 & 㴜 \\
\hline 害娄 & : & $\tilde{a}$ & : & 竞 & : & 号 & 哭 \\
\hline 畺 & 㖇 & 1 & I & 1 & 墨 & 学 & 熹 \\
\hline 思 & 嗬 & 哭 & 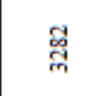 & $\stackrel{\mathscr{g}}{\mathrm{m}}$ & 总 & 啹 & 㱐 \\
\hline$\frac{\mathrm{d}}{\mathrm{d}}$ & $\begin{array}{l}\text { 侌 } \\
\text { 媂 } \\
\frac{\pi}{\pi}\end{array}$ & 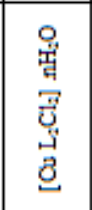 & 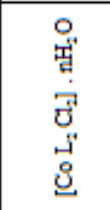 & 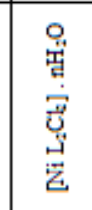 & 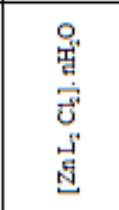 & 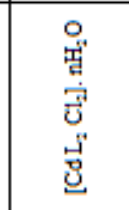 & 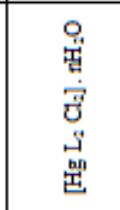 \\
\hline 2 & $\rightarrow$ & 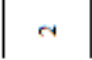 & $m$ & + & in & $\circ$ & r \\
\hline
\end{tabular}




\section{7-Electronic spectra and magnetic properties}

The electronic spectra data and the magnetic moment of prepared complexes,figures(18-24), the ligand is characterized by three absorption bands in UV-visible. These bands are appearing at the position $203 \mathrm{~nm}, 289$ $\mathrm{nm}$ and $432 \mathrm{~nm}$. The first one can be attributed to a $\pi \rightarrow \pi^{*}$ transition with in hetrocyclic imidazole ring[16] while the second UV band observed at a longer wavelength can be ascribed to the excitation of the $\pi$-electrons of the phenyl system.[17]. The third peak may be attributed to the $n \rightarrow \pi^{*}$ transition resulted from the presence of groups containing double bond, in addition to the presence of hetero atom carrying a lone pair of electrons such as $(-\mathrm{C}=\mathrm{N}-)$ and $(-\mathrm{C}=\mathrm{O})$ in addition to intermolecular chargetransfer taken place from benzene ring to the hetro imidazole ring through the azo $\operatorname{group}(-\mathrm{N}=\mathrm{N}-)$. $[18,19]$ This band showed at a red shift on coordination with a metal ions.[2,20] The magnetic susceptibility measurements show that:

1. The magnetic values of $\mathrm{Cu}$ (II) complexes were (1.75)B.M., which indicated the paramagnetic properties of single electron for these complexes that have octahedral configuration .These result were comparable to the theoretical value of spin moment(1.73)B.M. .

2. The $\mathrm{Co}(\mathrm{II})$ complexes give magnetic values (4.62) B.M., those values were consistent with the theoretical spin moment (4.15.2)B.M. of high spin octahedral complexes $\quad\left(\mathrm{t}_{2} \mathrm{~g}^{5} \quad \mathrm{eg}^{2}\right)$ which indicated spin-oribt coupling in other hand there is no change in cobalt oxidation state from $\mathrm{Co}$ (II) to Co(III).

3. The magnetic susceptibility measurements of $\mathrm{Ni}(\mathrm{II})$ complexes were (2.89)B.M., which belong to the two unpaired electrons of $\mathrm{Ni}(\mathrm{II})$, the excess in magnetic values attributed to distorted octahedral configuration.

4. All the magnetic values of group(IIB) divalent complexes of ( $\mathrm{Zn}, \mathrm{Cd}$ and $\mathrm{Hg}$ ) behave as diamagnetic complexes which confirm there is no change in mercury oxidation state.

According to these results the structural of these complexes may by proposed in this figure :
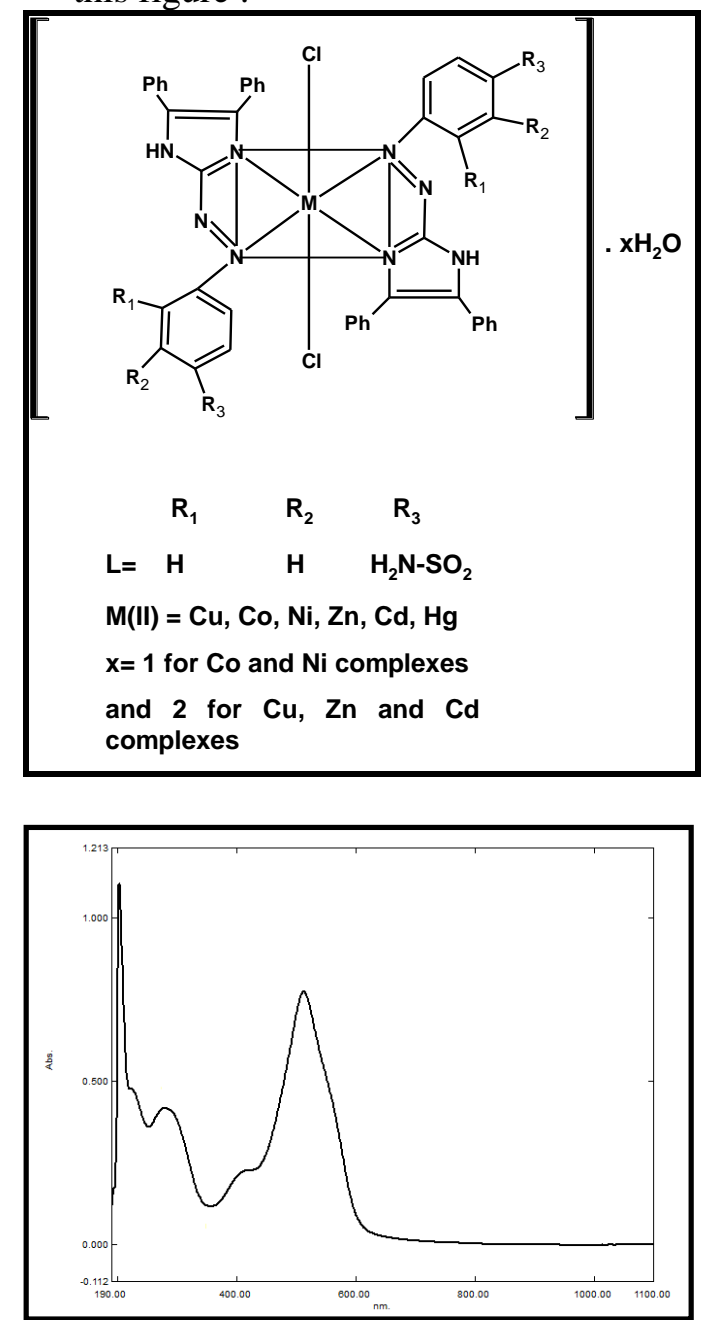

Fig.(18): UV-Vis spectra of [Cu (4SuBAI $)_{2} \mathrm{Cl}_{2}$. 


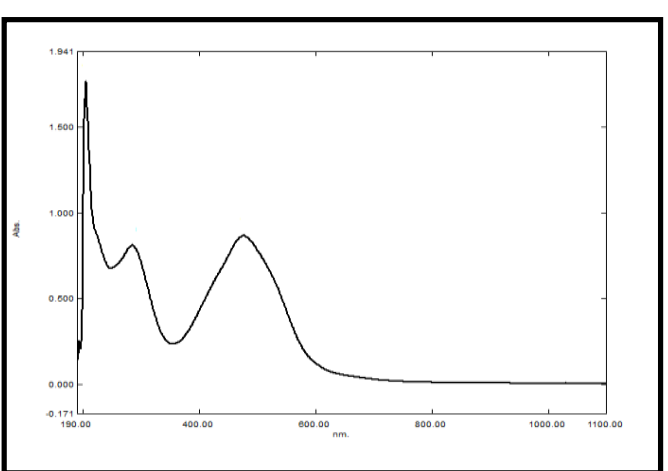

Fig.(19): UV-Vis spectra of [Co (4$\mathrm{SuBAI})_{2} \mathrm{Cl}_{2}$ ].

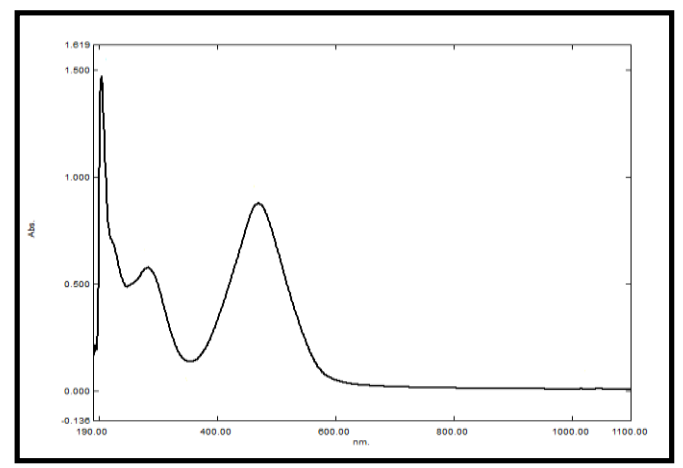

Fig.(20): UV-Vis spectra of [Ni (4$\mathrm{SuBAI})_{2} \mathrm{Cl}_{2}$ ].

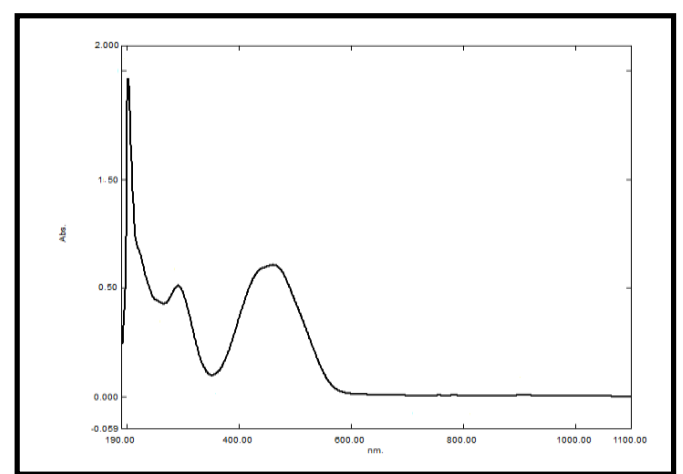

Fig.(21): UV-Vis spectra of [Zn (4$\operatorname{SuBAI})_{2} \mathrm{Cl}_{2}$ ].

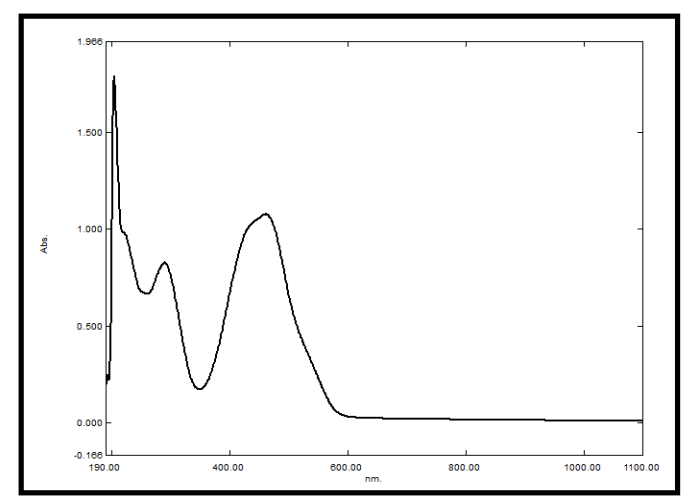

Fig.(22): UV-Vis spectra of [Cd (4$\left.\mathrm{SuBAI})_{2} \mathrm{Cl}_{2}\right]$.

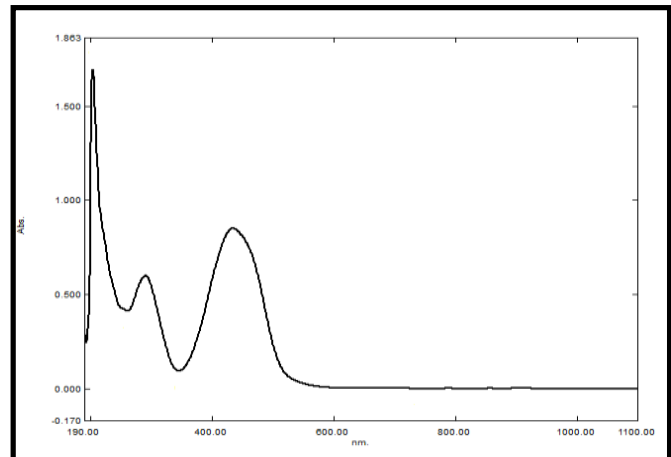

Fig.(23): UV-Vis spectra of [Hg (4$\operatorname{SuBAI})_{2} \mathrm{Cl}_{2}$.

\section{Conclusions:}

In this present study we report the preparation characterization and spectroscopy study of new azo ligand derived from imidazole and its complexes with $\mathrm{Cu}(\mathrm{II}), \mathrm{Cu}(\mathrm{II}), \mathrm{Ni}(\mathrm{II})$, $\mathrm{Zn}(\mathrm{II}), \mathrm{Cd}(\mathrm{II})$ and $\mathrm{Hg}(\mathrm{II})$ metal ions. The isolated complexes were characterized by available techniques. The aryl azo imidazole ligand (4SuBAI) behaves as a bidentate chelating agent and coordinating through the $\mathrm{N}_{3}$ atom of imidazole and another nitrogen atom of azo group which is the farthest of imidazole ring to form five-memberd metalo ring. The coordination of all metal ions with ligand (4-SuBAI) are to give hexa coordinated show octahedral stereochemistry.

\section{Reference:}

[1] Mathur, T.; Ray, U.S.; WU, J.C.; Lu, T.H. and Sinha, C. 2005. Tetra manganese (II) complexes of 1-alkyl-2-(arylazo) imidazole. Xray crystal structure of $[\mathrm{Mn}$ $\left.(\text { HaaiMe })_{4}\right] \quad\left[\mathrm{ClO}_{4}\right]_{2} . \quad$ DMF. J.Coord. Chem. 58:399.

[2] Savic, J. and Vasic, V. 2006. Complex formation between $\operatorname{Pd}(\mathrm{II})$ and immobilized imidazolazo-chromotropic acid .Acta Chim.Solv. 53:36-42.

[3] AL-adely, K. J. 2007. Preparation and spectral characterization of some transition metal complexes 
with new azo ligand 2-[(4Quinaldine)azo] - imidazole (QdAIm). J.Al-Qadisia for pure sci. 12(3):134-146.

[4] Mehdi, R. T. and Ali, A. M. 2005. Preparation and characterization of new azo imidazole ligand and some Transition Metal Complexes (NJC), 20:540-546.

[5]Marmion, D. M. 1999. Hand book of us colourant. Wiely, New York. 2:23-26.

[6]Mashaly, M. M.; Ramadan, A. T.; El-Shetary, B. A. and Dawoud, A. K. 2010. Azo complexes of $\mathrm{Cu}(\mathrm{II}), \mathrm{Co}(\mathrm{II})$, $\mathrm{Ni}(\mathrm{II}), \quad \mathrm{Cd}(\mathrm{II}), \quad \mathrm{Th}(\mathrm{IV}), \quad$ and UO2(VI) ions mixed ligand complexes, pyrolysis products and biological Activity. Synthesis and Reactivity in Inorganic and Metalorganic Chemistry; 34(8):13491378.

[7]Jancso, A.; Torok, I.; Korecz, L.; Rockenbaner, A. and Gajda, T. 2002. Metal ion coordination of a tripodal imidazole- derivative and its tridentate constituent equilibrium and structural studies. J. Chem. Soc. Dalton Trans; 26012607.

[8] Sadchikova, E. V. and Mokrushin, V. S. 2005. Reactivity of diazoazoles and azolediazonium salts in C-azo coupling reactions. Russian Chemical Bulletin; 54(2): 354-365.

[9] Santra, P. K.; Das, D.; Misra, T. K.; Roy R., Sinhaa C. and Pengb S. M. 1999. Chemistry of azopyrimidines Synthesis, spectral characterization, electrochemistry and X-ray crystal structure of bis[2-(arylazo)pyrimidine]

complexes of copper(I). Polyhedron; 18 :1909-1915.

[10] AL-Dheimy, M. H. S. 2007. Synthesis and spectral analysis of some lanthanide complexes with the new antipyrine -azo ligands;
Ph.D. thesis College of Science, University of Baghdad, Iraq.

[11] Ali, A. M.; Mohammed, H. J. and khadhium A. J. 2008. Preparation, identification and analytical studies of the ligand 2-[p- $\left(2^{\prime}-\right.$ pyrimidyl sulphamyI) phenylazo ]4,5-diphenyl imidazole (PSPAI) and some of it's metal complexes. The Islamic University Journal, 16(1):85-94.

[12] Santra, P. K.; Misra T. K.; Das D.; Sinha C.; Slawin A. M. Z. and Wollins J. D. 1999. Chemistry of azopyrimidines. Part II. synthesis, spectra, electrochemistry and Xray crystal structures of isomeric dichloro bis[2(arylazo)pyrimidine] complexes of ruthenium(II). J.polyhedron; 18:2869.

[13] Shibata, S.; Furukawa, M. and Nakashima, R. 1976.Syntheses of azo dyes containing 4,5diphenylimidazole and their evaluation as analytical reagents. Anal. Chem. Acta.; 81:131.

[14] Witwit, A. N. K. 2004. Synthesis and spectral, study of group (IIB) metal ions complexes with new organic reagent 2- (2, 4 Dinitro phenyl azo ) 4,5 - diphenyl imidazole; M.Sc. thesis College Education for Women, University of AL-Kufa.

[15] kaji, N. and Solomon, P. H. 1977. Infrared Absorption spectroscopy practical. $2^{\text {th }} \mathrm{Ed}$; sanfrancisco; Holden. Day.

[16] Figgis, B. N. and Lewis. 1960. Modern coordination chemistry. Interscience, New York.

[17]Nicholas, D. 1973.pergamon Texts in Inorganic chemistry" pergamon press. Oxford $1{ }^{\text {st }}$ Ed.

[18] Ali, A. M., Mohammad, M. S. and Kudair, H. N. 2007. Synthesis and structural studies of some transition metal complexes using 2-[(5-Chloro-2-methyl phenol) 
azo]-4,5-diphenyl imidazole (CIMPAI) as new ligand. J.Al. Qadisiya for pure sci. 12(2):133141.
[19] Seiwood, P. W. 1976. Magneto chemistry. Inter science, New York.

[20]Skooge, A., West, M. and James F. 1997. Fundamentals Analytical Chemistry, $7^{\text {th }}$ Ed. New York.

\section{تحضير وتثخيص بعض المعقدات لليكاند الازو غير متجانس الحلقة20-2 (4)- سلقو امايد فنيل) ازو4,4ثنائي فنيل اميدازول}

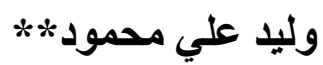

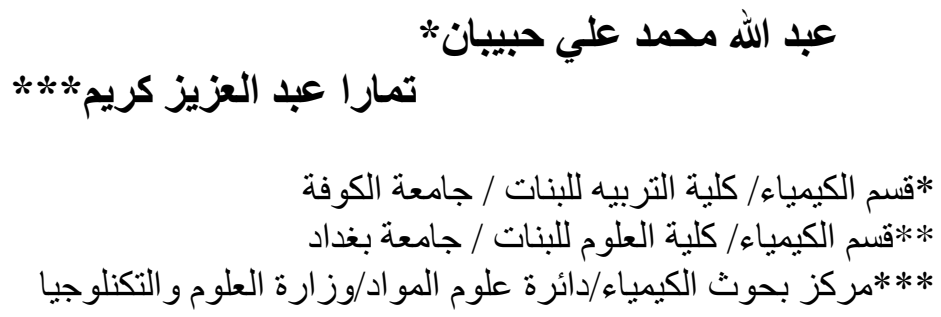

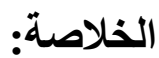

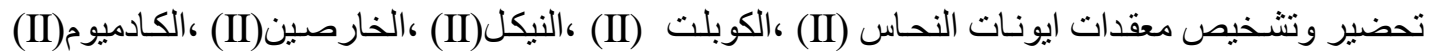

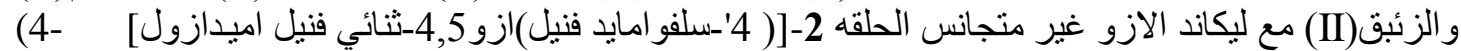

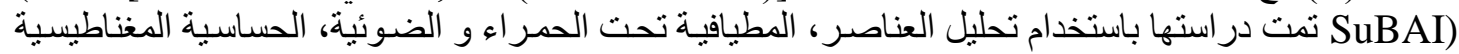

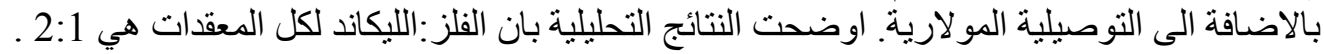

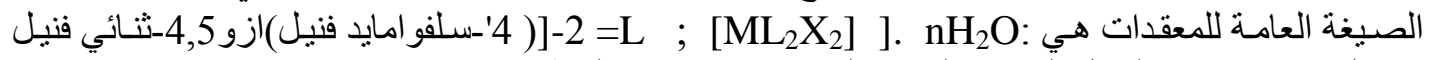
اميدازول] و Cl =X و الثنكل الفر اغي لجميع المعقدات هو ثماني السطوح ـ الكلمات المفتاحية: مو اصفات، معقدات الفلزات، حلقية غير متجانسة ، ازو ، ليكاند. 